\title{
The Knight-service of Malmesbury Abbey
}

ONE of the omissions in the returns of knights' fees (cartae baronum) in 1166. is a carta for Malmesbury Abbey. Its abbot had paid scutage as for three knights in 1156 and 1161 , but the absence of a return for the abbey in 1166 was followed by the absence of any. payments from it to the 'aid' for the king's daughter's marriage in $1168 .^{1}$ Such omissions were partly rectified by the scutage for Ireland in 1172, under the several headings 'De hiis qui cartas non miserunt'. The sheriff of Wiltshire, who had been in charge of the abbey's revenues during a vacancy, ${ }^{2}$ accounted, under this heading, 'de lxs. de scutagio militum Abbatie de Malmesberia ' 3 This payment implies throe knights' fees.

Whether or not the omission of a return in 1166 was due to a difficulty caused by the peculiar character of the abbey's knights? fees, the ascertainment of the 'service' due from them led to the drawing up of a record of exceptional interest. 4 This was a formal 'recognition' by the abbey's knights in the Curia Regis of the services due from each of them. Its heading and the first entry run as follows:

Haec sunt servicia quae milites de abbatia Malmesburiae recognoverunt in curia domini regis coram Ricardo de Luci, et Reginaldo comite Cornubire, et Willelmo comite de Mandeville, et Ricardo Archidiacono Pictaviae, et Gaufrido archidiacono Cantuar[iensi] et Ricardo regis thesaurario, et Rannulfo de Glanville, et Thoma Basset, se debere abbati Malmesburiae domino suo.

Ávene. Filius comitis Patricii debet abbati servicium unius militis, in homagio, et relevio et auxiliis. Et praeterea faciet servicium dimidiae partis feudi unius militis de regali servicio.

With regard to the date, the names given indicate the years 1168-74. William de Mandeville, earl of Essex, did not succeed to the earldom till late in 1166, and 'the son of earl Patrick' was clearly that William whose father, Patrick, earl of Salisbury, died 27 March 1168. The names of the two archdeacons, of course, prove that the record cannot be later than 1174; whether it was previous to the scutage charged in 1172 it might be rash to say.

In Feudal England (pp. 244-5) I have discussed the ascertainment of knight-service from the knights themselves by inquest. The nearest parallel to the Malmesbury 'recognition' is that of the knight-service due from the Honour of Arundel, which I have

1 Pipe Roll, 14 Hen. II, pp. 160-1.

- The Rolls show that they had come into the king's hands in the fiscal year 1168-9, and that those for 1171-2 were restored to Robert, then abbot.

- Pipe Roll, 18 Hen. II, p. 128.

- Registrum Malmesburiense, i, 277-8. 
there cited. ${ }^{5}$ There is mention in the Malmesbury Register of what seems to be another recognition on the subject. Queen Eleanor issued a precept to the knights of the abbey :

Quod faciatis abbati de Malmesburia servicium de feodis vestris integre et plenarie, sicut recognitum fuit ante regem et iusticiarios apud Wygorniam. ${ }^{6}$

The distinctive and perhaps unique feature of the service due from the abbey's knights is its double assessment. This system is duly seen in the first entry, printed above, and it figures similarly in each successive entry. For the purpose of reckoning the service due to the abbot in (1) homage, (2) relief, (3) aids, the holding was assessed much higher than it was for the purpose of paying the service due to the king (regale servitium). Another return, of later date, ${ }^{7}$ records the same double assessment (pp. 245-8) and adds the hidage for each holding. In tabular form the figures are these :

Service dof from the knights of Malmesbury Abbey circ. 1170

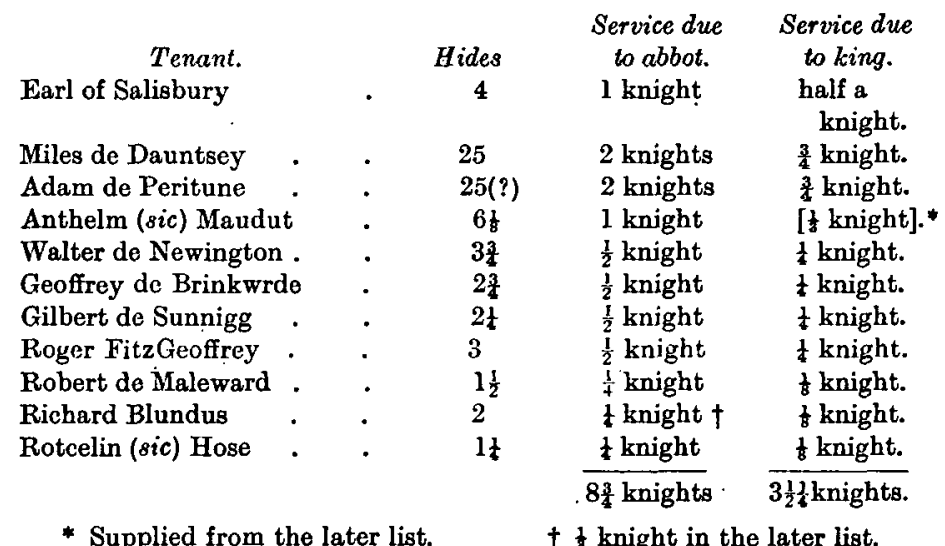

Opposite this return is an abstract (p. 276), 'De scutagio baronum', based on the later of the two returns, which confirms (the scutage being reckoned at forty shillings on the fee) the figures given above for the service due to the king so far as it is possible to identify the holdings. The total, however, is a difficulty, implying, as it does, six fees. ${ }^{8}$ Another difficulty is the fact that the rolls, from 1172 , steadily record the knight-

B 'Rex Henricus ... fecit eos recognoscere servitia militum de honore, et super legalitatem et sacramenta eorum inde neminem audire voluit': Red Book of the Exchequer, p. 201.

- Reg. Malmesb., i. 335.

7 The holding of the earls of Salisbury was then in the hands of the earl of Lincoln in right of his wife (1257-1311).

- 'Summa totius scutagii, viilit. xviiis. iiiid. Et ad complendam summam de xiili, solvet abbas, lxiis. viiid.' (p. 2'ii). 
service of the abbey as exactly three knights. Moreover, a list of the 'Milites abbatis Malmesburiae' in the Red Book (p. 605), though giving a later return, ${ }^{9}$ closes with the words 'De hiis debet iii .milites'. The actual total entered is $4 \frac{83}{240}$ milites. Yet another important document in the Malmesbury Register is headed 'Turni ad faciendum regale servitium in exercitu regis' (i. 248) ; here the holdings are arranged in three groups, each of which was evidently responsible for finding one knight. The three holdings in the first of these groups owed, 'ad faciendum regale servitium', $1 \frac{7}{12}$ knights, so that the disproportion was as marked in the group as in the total of knight-service.

We are here reminded of the well-known system by which the .knight-service due from Ramsey Abbey was discharged.10 The four knights whom the abbey had to provide, for the discharge of its service, were elected in the abbot's feudal court at Broughton by his knights and freeholders. ${ }^{11}$ The mention of freeholders reminds me of yet another Malmesbury Abbey document (i. 250). This is a sealed certificate, of about 1280-90, from the knights and freeholders of the abbot of Malmesbury, testifying that John Comyn, lord of Newbold (Warwickshire) and Walcote (Wiltshire), and his predecessors had done their share of the regale servitium due from them along with their predecessors and themselves.

Universis notum facimus, quod quotienscumque regale servicium a praedicto abbate de Malmesburia domino nostro exigitur, omnes antecessores nostri et nos una cum Iohanne Comyn, domino de Nywebold et de Walecote, participe nostro in omnibus serviciis praedicto domino nostro debitis, pro tenementis quae de eodem abbate tenemus, regale servicium eidem domino nostro, et omnibus antecessoribus suis, semper fecimus et facimus, et facere debemuś. Et omnia eadem servicia quae - dicto abbati, domino nostro, pro tenementis nostris facimus, idem dictus Iohannes Comyn et omnes antecessores sui, eidem abbati, et omnibus antecessoribus suis, pro tenementis suis praedictis semper facere solent et debent.

The first four names on the list are followed by the word 'milites'; the royal service due from these was $\frac{3}{4}, \frac{1}{2}, \frac{1}{1}$ and [ $]^{12}$ of a knight. Then come the names of ten others who are known to have owed knight-service, followed by the noteworthy phrase 'et caeteri libere tenentes abbatis Malmesburize'. So the abbey's tenants by knight-service comprised two classes; ( $a$ ) 'milites', $(b)$ ' libere tenentes'.

- It was probably entered to supply the lack of a return (carta) in 1166.

10 See Feudal England, pp. 297-8.

14 'Omnes' milites et libere tenentes de curia de Brouctop.' See Select. Pleas in Manorial Courts, od. Maitland (Selden Society), pp. 50, 61-2. Maitland cites a valuable parallel concerning the knight-service of St. Albans Abbey, where some of the six fees ('sex milites feffatos ') were held by groups of men.

12 I am not sure as to William de Lavaham (the,fourth namo). 
Apart from the 'regale servitium' and from the homage, aid, and relief due to the abbot, these tenants owed him also-as is shown by what I have termed the later list (pp. 245-8)-(1) 'hundredselver', (2) Peter's pence. ${ }^{13}$ From the documents relating to a long suit concerning the wardship of John Comyn, it appears that these tenants also owed (3) suit to the abbot's threeweekly court at Malmesbury. A charter of Henry II, entered in the Register (i. 331), remits to the abbot and monks their annual payment of $f 6 \mathrm{l0s}$. for 'hundredselver', which it explains as a commutation for quittance of shire and hundred courts. ${ }^{14}$ This remission figures annually on the Pipe Rolls of his reign. ${ }^{15}$

Although the system by which Ramsey Abbey discharged the knight-service due from it ${ }^{16}$ attracted the attention both of Stubbs and of Maitland, it has hitherto, I believe, escaped notice that the knights of the bishop of Chichester also held by a peculiar tenure. This I have only been able to deduce from the Pipe Roll of 1171. The revenues of the see were at that time in the hands of the king, ${ }^{16}$ to whom, consequently, were paid all 'reliefs' that fell due during the vacancy. It is well recognized that in such cases, both on lay and on church fiefs, the relief payable was $f 5$ from each knight's fee in the holding, fifty shillings from half a fee, and so on. The Chichester system was quite different; the holdings, indeed, were reckoned in terms of the knight's fee, but when relief had to be paid, it was reckoned at the rate of one marc on each hide held, quite irrespective of knight-service. This was explained as 'per consuetudinem episcopatus' and was defined as ' 1 marcam de unaquaque hida'. Of those who paid relief in 1171 William FitzMalger, William de Irham, Robert Peterel, and William de Selsey can be identified, with the help of the bishop's carta in 1166,18 as among the tenants of knights' fees. One is here reminded of the system existing on the Ramsey Abbey fief, ${ }^{19}$ and in view of the tenure of single fees on the bishop of Chichester's fief by groups of four and even, in one case, ten tenants, there may well have been there some such system of election for the discharge of knight-service in the field as in the cases of Ramsey and St. Albans. J. H. RouND. in 249 .

13 Special lists, giving the details of both payments, will be found in the Register,

14 'Pro quietancia scirarum et hundredarum, quas ipsi solent appellare hundredselver.'

${ }^{25}$ E.g. 'Monachis de Malmesberia vili. et $\mathbf{x}$. pro Sciris et hundredis per breve Regis' (Pipe Roll, 5 Hen. II, p. 38).

:s Red Book, pp. 371-2. 17 Pipe Roll, 17 Hen. II, pp. 134-6.

${ }^{18}$ Red Book, p. 199 . The case of William de Selsey is further remaitkable because his payment of 5 s. would represent 3 hide. In Domesday a 'William' held exactly hide of the bishop's manor of Selsey.

19 Feudal England, pp. 297-8 ; Miss Neilson's Economic Conditions on the Manors of Ramsey Abbey, pp. 25-6. 